\title{
Ectopic bronchogenic cyst arising from the diaphragm: a rare case report and literature review
}

\author{
Juan Tang ${ }^{\dagger}$, Zhen Zeng ${ }^{\dagger}$, Senyi Deng and Feng Lin*
}

\begin{abstract} BC. removed.

Keywords: Case report, Bronchogenic cyst, Thoracoscopic surgery

\section{Background}

Bronchogenic cysts (BCs) are congenital malformations of the ventral foregut, caused by abnormal sprouting of the original tracheobronchial tree. They are usually located in the mediastinum, lungs, and other rare places, depending on the level of abnormal budding that occurred during development [1]. Occurrence of bronchogenic cyst in the diaphragm is extremely rare. Here, we report a case of ectopic bronchogenic cyst arising from the diaphragm in an adult. This case was confused with a lung tumor before operation at radiological imaging. Eventually, the patient underwent successful minimally invasive surgery with a smooth recovery.
\end{abstract}

Background: Bronchogenic cysts can be caused by errors in the growth of the ventral foregut. Localization of the bronchogenic cyst $(\mathrm{BC})$ varies depending on the level of the abnormal budding. They are usually located in the lungs and mediastinum. BCs of the diaphragm are a rare form of this abnormality.

Case presentation: A 66-year-old woman coughs and expectorates. CT scan evaluation revealed a soft tissue shadow of $6 \times 5 \mathrm{~cm}$ in the left lung. Under thoracoscopic surgery, we found that the mass originated from the diaphragm away from the lung tissue, we completely removed the mass and the pathological result was diagnosed as

Conclusions: The prognosis of ectopic BC is usually optimistic for benign tumors, as long as the tumor is completely

\footnotetext{
*Correspondence: linfeng0220@yeah.net

†Juan Tang and Zhen Zeng contributed equally to this work

Department of Thoracic Surgery, West China Hospital, Sichuan University,

No. 37, Guoxue Alley, Sichuan 610041 Chengdu, China
}

\section{Case presentation}

A 66-year-old woman presented with a 6-month history of cough with blood in the sputum. The patient was treated with antibiotics without significant relief of symptoms by pulmonologist. She denied fever, chest pain and tightness. Clinical history and family history were uneventful. Physical examination revealed all vital signs were normal. The laboratory data revealed a slightly elevated folate receptor-positive circulating tumor cells count of $14.0 \mathrm{FU} / 3 \mathrm{~mL}$. Then, a computed tomography $(\mathrm{CT})$ of chest with contrast was performed, which showed a $6 \times 5 \mathrm{~cm}$ soft tissue in the posterior basal segment of the left lower lobe of the lung, and its adjacent pleura was thickened (Fig. 1 A, B, arrows). Since the diagnosis of the tumor could not be ruled out, the patient underwent an exploratory video-assisted thoracic surgery (VATS) with general anesthesia. During operation, a $6 \times 5 \times 2 \mathrm{~cm}$ lamellar cystic tumor arising from the diaphragm, adjacent to the chest wall, was found (Fig. 2) and the cystic tumor was completely resected through linear 

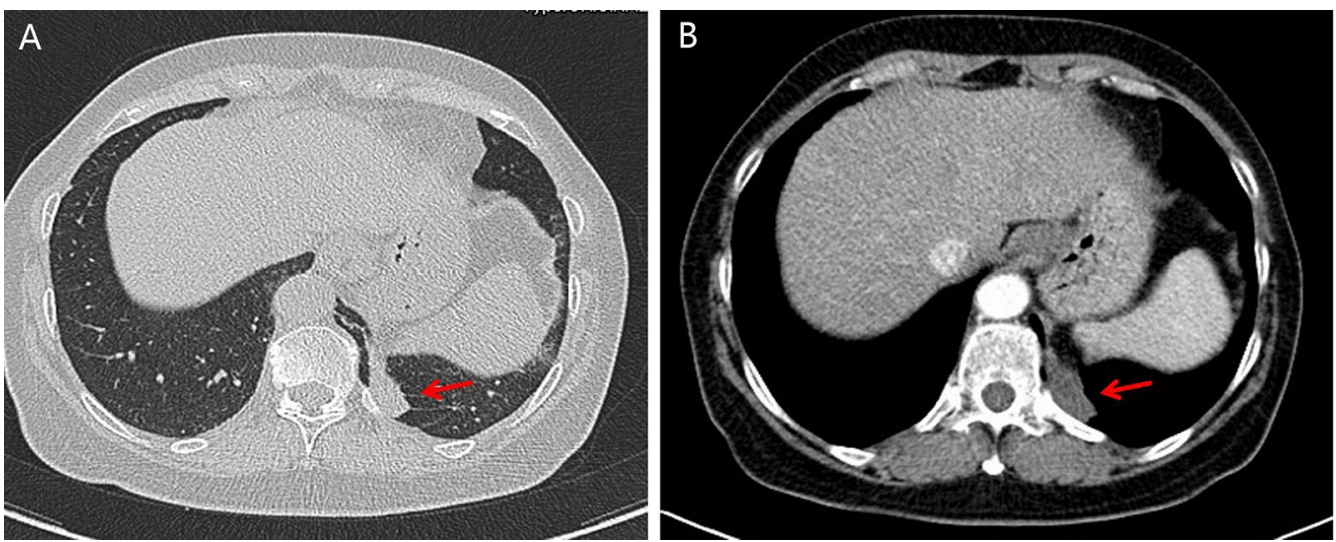

Fig. 1 A, B Computed tomography (CT) of chest with contrast showed a $6 \times 5 \mathrm{~cm}$ soft tissue in the posterior basal segment of the left lower lobe of the lung, and its adjacent pleura is thickened (arrows)

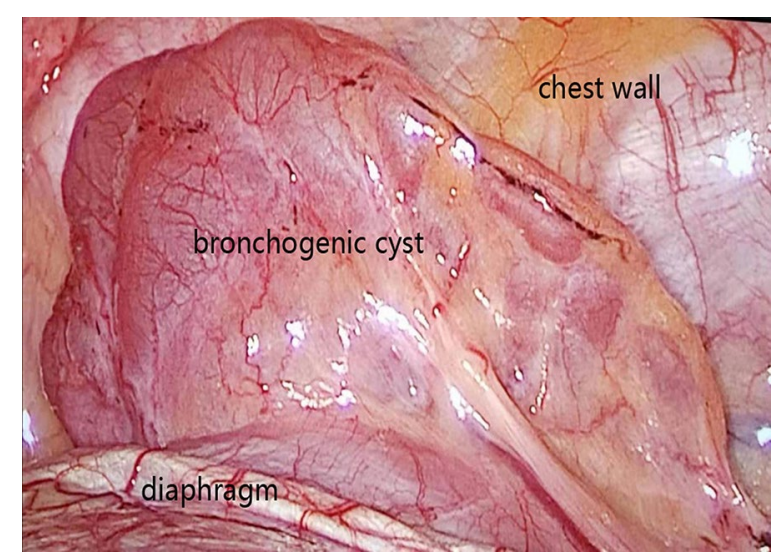

Fig. 2 During operation, a $6 \times 5 \times 2 \mathrm{~cm}$ lamellar cystic tumor arising from the diaphragm, adjacent to the chest wall, was found (arrow) cutting stapler. Histopathologic examination indicated a cystic structure filled with thick white mucus (Fig. 3). Microscopically the cyst was composed of smooth muscle, loose connective tissue, and pseudostratified ciliated columnar epithelium without cellular atypia. After operation, he was given routine antibiotics to prevent infection for 2 days. The patient was discharged after an uneventful postoperative recovery.

\section{Discussion and conclusions}

$\mathrm{BC}$ is a kind of rare benign tumor originated early in lung bud development before bronchus formation. Clinically, $\mathrm{BCs}$ are usually located in the lung parenchyma or mediastinum [2, 3], but in some case they may break away and migrate to other locations $[4,5]$. Therefore, BCs can be divided into three types: intrapulmonary, mediastinal and
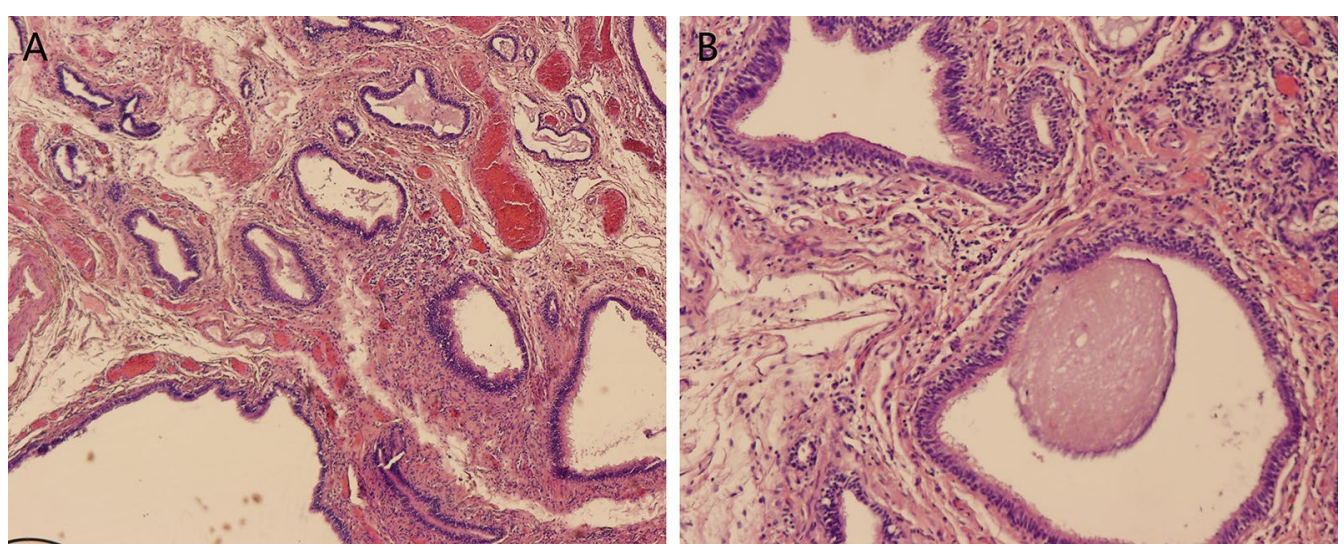

Fig. 3 Histopathologic examination indicated the cyst was composed of smooth muscle, loose connective tissue, and pseudostratified ciliated columnar epithelium without cellular atypia (Haematoxylin and eosin stain, $\mathbf{A}$ original magnification $\times 4$, $\mathbf{B}$ original magnification $\times 10$ ) 
ectopic, according to the location of lesions [6]. Of these, the incidence of ectopic type is the lowest. Usually, most patients have no or minimal clinical symptoms caused by compression of surrounding structures or complications related to cysts [5].

Ectopic BCs are extremely uncommon. The literature review (Table 1) reveals that few cases of ectopic $\mathrm{BCs}$ have been reported in the past 15 years [1-24]. The most common sites are neck, thyroid, stomach, esophagus, scapular, parietal pleura and pericardium. Rare cases occurring in diaphragm have also been reported $[19,20]$. As for ectopic BC in diaphragm mimicking lung tumor similar to our report, only 1 cases have been reported in the English literature up to now [25] and 2 cases in another language $[26,27]$. Usually, there is a direct correlation between clinical symptoms and lesion sites [13], and the patients of ectopic BCs may present a series of symptoms such as abdomen pain (stomach), dysphagia (esophagus),dyspnea (neck) and chest pain (pericardium). In addition, there are some potential complications of $\mathrm{BC}$ including infection, rupture of the cyst, bleeding, and even malignant transformation $[2,14]$.

Radiological examination has great clinical value for the early discovery of ectopic BCs [10]. However, due to the lack of specific manifestations at CT or magnetic resonance imaging (MRI) [28], it is easy to be confused with common primary organ disease, and the misdiagnosis rate of this disease may reach 40 to $60 \%$ [6]. In some literature reports, ectopic BCs have been confused with peripheral lung neoplasm, diaphragmatic tumor, diaphragmatic hernia, neurogenic tumor, hydatid cysts, and esophageal diverticulum [20]. In our case, the patient was initially diagnosed with a lung tumor due to respiratory symptoms and atypical CT images. She had been treated with conservation therapy but did not relieve. A complete excision was considered to be an effective therapeutic strategy. The cyst arising from the diaphragm was not found until the operation, and the pathological examination confirmed the diagnosis of ectopic BC.

Considering the potential risk of complications and malignant transformation, complete surgical resection is recommended even for asymptomatic patients [5]. Minimally invasive surgery, such as VATS, is a valuable diagnostic method to identify the location of lesions and then help diagnosis [2]. In some complex cases, transtracheal and percutaneous cyst aspiration has been proposed as an alternative to surgery, but it has not been widely accepted due to possible high incidence of recurrence. In

Table 1 The reported case of ectopic bronchogenic cyst in the past 15 years

\begin{tabular}{|c|c|c|c|c|c|c|c|c|}
\hline $\mathbf{N}$ & Author & Age & Sex & Location & Size $(\mathrm{cm})$ & Symptom & Treatment & Follow-up \\
\hline 1 & Mir ZM [1] & 5 & $F$ & Scapular & $3.9 \times 2.9 \times 3.7$ & Cellulitis & Surgical resection & No recurrence \\
\hline 2 & Cheng Y [2] & 30 & M & Esophagus & $4.0 \times 7.0 \times 8.0$ & Dysphagia & Surgical resection & No recurrence \\
\hline 3 & Kün-Darbois [3] & 0.25 & $\mathrm{~F}$ & Tongue & $d=1.0$ & Swelling of tongue & Surgical resection & No recurrence \\
\hline 4 & Sang YS [4] & 62 & $\mathrm{~F}$ & Stomach & $\mathrm{d}_{=} 1.6$ & None & Surgical resection & No recurrence \\
\hline 5 & Chhaidar A [5] & 65 & $\mathrm{~F}$ & Stomach & $8.0 \times 7.0$ & Epigastric pain & Surgical resection & No recurrence \\
\hline 6 & Xiao J [6] & 62 & $\mathrm{~F}$ & Stomach & $7.0 \times 4.5 \times 1.5$ & Abdomen pain & Surgical resection & No recurrence \\
\hline 7 & Usamah M [7] & 7 & M & Neck & $4.0 \times 3.0$ & None & Surgical resection & No stated \\
\hline 8 & Ustundag E [8] & 5 & $F$ & Thyroid & $2.0 \times 2.0$ & Swelling & Surgical resection & No stated \\
\hline 9 & Somwaru LL [9] & 3 & $\mathrm{~F}$ & Intrapericardial & $4.0 \times 2.0$ & No stated & Surgical resection & No stated \\
\hline 10 & Nakagawa M [10] & 1.25 & $\mathrm{~F}$ & Parietal pleura & $2.1 \times 1.8$ & Fever & Surgical resection & No stated \\
\hline 11 & Petraud A [11] & 22 & $M$ & Tongue & $d=2.0$ & Painful & Surgical resection & No stated \\
\hline 12 & Al-Balushi Zi [12] & 3 & $M$ & Scapular & $4.0 \times 3.5 \times 2.0$ & None & Surgical resection & No stated \\
\hline 13 & Lu Q [13] & 46 & $M$ & Pericardium & $10.0 \times 8.0 \times 7.0$ & Dyspnea, chest pain & Surgical resection & No recurrence \\
\hline 14 & Sun L [14] & 67 & $M$ & Stomach & $d=5.0$ & Epigastric pain & Surgical resection & No recurrence \\
\hline 15 & Kiralj A [15] & 6 & $\mathrm{~F}$ & Neck & $3.5 \times 4.0$ & Dyspnea & Surgical resection & No recurrence \\
\hline 16 & Liu Z [16] & 70 & $F$ & Neck & $3.3 \times 3.0$ & Painful mass & Surgical resection & No recurrence \\
\hline 17 & Yang X [17] & 40 & $M$ & Esophagus & $3.0 \times 2.0$ & None & Surgical resection & No recurrence \\
\hline 18 & Xiang J [18] & 23 & $M$ & Esophagus & $4.5 \times 3.8$ & Dysphagia & Surgical resection & No stated \\
\hline 19 & Mubang R [19] & 41 & $M$ & Diaphragm & $4.5 \times 5$ & Back pain & Surgical resection & No stated \\
\hline 20 & Jiang C [20] & 38 & $\mathrm{~F}$ & Diaphragm & $5 \times 5 \times 4$ & None & Surgical resection & No recurrence \\
\hline 21 & Shah SK [21] & 1.9 & $\mathrm{~F}$ & Subcutaneous & $d=1.5$ & Fluctuant mass & Surgical resection & No stated \\
\hline 22 & Borgnat F [22] & 5 & $\mathrm{~N} / \mathrm{A}$ & N/A & N/A & N/A & Surgical resection & No stated \\
\hline 23 & Parambil JG [23] & 38 & $M$ & Mediastinum & $4.4 \times 2.4 \times 4.5$ & Atrial fibrillation & Surgical resection & No recurrence \\
\hline 24 & Kubouchi Y [24] & 19 & $M$ & Mediastinum & $3.5 \times 2.0$ & None & Surgical resection & No stated \\
\hline
\end{tabular}


general, the prognosis of ectopic BC is usually optimistic for benign tumors, as long as the tumor is completely removed [29].

\author{
Abbreviations \\ BC: Bronchogenic cyst; CT: Computed tomography; VATS: Video-assisted \\ thoracic surgery; MRI: Magnetic resonance imaging.
}

\section{Acknowledgements}

Not applicable.

\section{Authors' contributions}

JT makes substantial contributions to the conception of the work. ZZ has made substantial contributions the acquisition data. JT and ZZ are the major contributors in writing the manuscript. ZZ and SYD revise the manuscript. FL designs the study and revises the manuscript. All authors read and approved the final manuscript.

\section{Funding}

This study is supported by the key research and development program (2019YFS0335), Science \& Technology Department of Sichuan Province. Feng Lin is the funder who plays the role of in the design of the study and review the manuscript.

\section{Availability of data and materials}

Not applicable.

\section{Declarations}

\section{Ethics approval and consent to participate}

Not applicable.

\section{Consent for publication}

Written informed consent was obtained from the patient for publication of this case report and any accompanying images. A copy of the written consent is available for review by the Editor-in-Chief of this journal.

\section{Competing interests}

All authors have no conflict of interest or financial ties to disclose.

\section{Received: 13 October 2020 Accepted: 2 August 2021}

Published online: 10 August 2021

\section{References}

1. Mir ZM, Wang A, Winthrop A, Kolar M. Scapular bronchogenic cyst in a girl presenting as recurrent cellulitis: a case report and review of the literature. Int J Surg Case Rep. 2018;2018:1-4. https://doi.org/10.1155/ 2018/7463724.

2. Cheng Y, Chen D, Shi L, Yang W, Chen Y. Surgical treatment of an esophageal bronchogenic cyst with massive upper digestive tract hematoma without esophagectomy: A case report and the review of the literature. Therap Clin Risk Manag. 2018;14:699-707. https://doi.org/10.2147/TCRM. S153145.

3. Kün-Darbois JD, Breheret R, Bizon A, Paré A, Laccourreye L. Bronchogenic cyst of the tip of the tongue: report of two cases. Eur Ann Otorhinolaryngol Head Neck Dis. 2015;132:49-51. https://doi.org/10.1016/j.anorl.2013. 11.007.

4. Sang YS, Noh JH, Lee SJ, Son HJ. Bronchogenic cyst of the stomach masquerading as benign stromal tumor. Pathol Int. 2005;55:87-91. https:// doi.org/10.1111/j.1440-1827.2005.01788.x.

5. Houssem AC, Ammar N, Abdessayed M, Azzaza RG. Large bronchogenic cyst of stomach: a case report. Int J Surg Case Rep. 2017. https://doi.org/ 10.1016/j.ijscr.2017.03.021.

6. Xiao J, Zhang R, Chen W, Wu B. Ectopic bronchogenic cyst of the gastric cardia considered to be a gastrointestinal stromal tumor before surgery: a case report. BMC surg. 2020;20:42. https://doi.org/10.1186/ s12893-020-00704-Z.

7. Hadi UM, Jammal HN, Hamdan AL, Saad AM, Zaatari GS. Lateral cervical bronchogenic cyst: an unusual cause of a lump in the neck. Head Neck. 2001;23:590-3. https://doi.org/10.1002/hed.1082.

8. Ustundag E, Iseri M, Keskin G, Yayla B, Muezzinoglu B. Cervical bronchogenic cysts in head and neck region. J Laryngol Otol. 2005;119:419-23. https://doi.org/10.1258/0022215054273188n.

9. Somwaru LL, Midgley FM, Russo GBD. Intrapericardial bronchogenic cyst overriding the pulmonary artery. Pediatr Cardiol. 2005;26:713-4. https:// doi.org/10.1007/s00246-004-0902-3.

10. Nakagawa M, Hara M, Oshima H, Shibamoto Y, Sato Y, Kondo S, Suzuki T, Takahashi S. Pleural bronchogenic cysts: imaging findings. J Thorac Imaging. 2008;23:284-8. https://doi.org/10.1097/RTI.0b013e318176b935.

11. Petraud A, Khonsari RH, Corre P, Mercier JM. Bronchogenic cyst of the tongue in an adult. Rev Stomatol Chir Maxillofac. 2010;111:46-8. https:// doi.org/10.1016/j.stomax.2009.10.005.

12. Al-Balushi Z, MTE, AI SD, Al RM. Scapular bronchogenic cyst: a case report and literature review. Oman Med J. 2012;27:161. https://doi.org/10.5001/ omj.2012.33.

13. Lu Q, Yang E, Wang W, Wang X, Li X. Spontaneous rupture of a giant intrapericardial bronchogenic cyst. Ann Thorac Surg. 2013;96:e109-10. https:// doi.org/10.1016/j.athoracsur.2013.05.095.

14. Sun L, Lu L, Fu W, Li W, Liu T. Gastric bronchogenic cyst presenting as a gastrointestinal stromal tumor. Int J Clin Exp Pathol. 2015;8:13606-12.

15. Kiralj A, Vukovi N, Mijatov I. Congenital cervical bronchogenic cyst: a case report. Srp Arh Celok Lek. 2015;143:317-21. https://doi.org/10.2298/sarh1 $506317 \mathrm{k}$

16. Liu Z, Tian Z, Zhang C, He Y. Ectopic congenital bronchogenic cyst accompanied by infection appearing in the cervical region of an elderly female patient: a case report. Oncol Lett. 2016;11:1065-8. https://doi.org/ 10.3892/ol.2015.4022

17. Yang $X$, Zong Y, Zhao H-Y, Wu Y-D, Ji M. Complete excision of esophageal bronchogenic cyst by endoscopic submucosal tunnel dissection: a case presentation. BMC Gastroenterol. 2019;19:155. https://doi.org/10.1186/ s12876-019-1072-3.

18. Xiang J, Linghu $\mathrm{E}$, Chai N. Case of large intra-esophageal bronchogenic cyst treated with lauromacrogol ablation. Dig Endosc. 2020;32:435. https://doi.org/10.1111/den.13609.

19. Mubang R, Brady JJ, Mao M, Burfeind W, Puc M. Intradiaphragmatic bronchogenic cysts: case report and systematic review. J Cardiothorac Surg. 2016:11:79. https://doi.org/10.1186/s13019-016-0444-9.

20. Jiang C, Wang $H$, Chen G, Jiang G, Zhang P. Intradiaphragmatic bronchogenic cyst. Ann Thorac Surg. 2013;96:681-3. https://doi.org/10.1016/j. athoracsur.2012.10.031

21. Shah SK, Stayer SE, Hicks MJ, Brandt ML. Suprasternal bronchogenic cyst. J Pediatr Surg. 2008;43(11):2115-7. https://doi.org/10.1016/j.jpedsurg. 2008.07.029.

22. Borgnat F, Lupu Bratiloveanu P, Gyenes C, Le Bescond Y. Kyste bronchogénique cervical chez un enfant [Bronchogenic cervical cyst in a child]. Rev Stomatol Chir Maxillofac. 2011;112(1):54-6. https://doi.org/10.1016/j. stomax.2011.01.001 French.

23. Parambil JG, Gersh BJ, Knight MZ, Krowka MJ, Ryu JH. Bronchogenic cyst causing atrial fibrillation by impinging the right inferior pulmonary vein. Am J Med Sci. 2006;331(6):336-8. https://doi.org/10.1097/00000441200606000-00010.

24. Kubouchi Y, Nakamura H, Fujioka S, Miwa K, Takagi Y, Yurugi Y, Haruki T, Taniguchi Y. Thoracoscopic resections of bronchogenic cysts arising in the posterior mediastinum: a report on 3 patients. Yonago Acta Med. 2010:53(4):77-81.

25. Chang YC, Chen JS, Chang YL, Lee YC. Video-assisted thoracoscopic excision of intradiaphragmatic bronchogenic cysts: two cases. J Laparoendosc Adv Surg Tech A. 2006;16(5):489-92. https://doi.org/10.1016/j.athor acsur.2012.10.031.

26. Msika S, Kianmanesh R, Jouet P, Brun P, Deroide G, Barge J, Soule JC, Hay $J M$. Bronchogenic cyst of the right hemidiaphragm mimicking a hydatic cyst of the liver. Gastroenterol Clin Biol. 2000;24(12):1224-6.

27. Desrumaux I, De Wever W, Verschakelen J. Paravertebral and diaphragmatic mass: an ectopic location of bronchogenic cyst. JBR-BTR. 2001;84(1):8-9. 
28. Agrusa A, Romano G, Chianetta D, De Vita G, Frazzetta G, Di Buono G, Sorce V, Gulotta G. Right diaphragmatic injury and lacerated liver during a penetrating abdominal trauma: case report and brief literature review. World J Emerg Surg. 2014;9:33. https://doi.org/10.1186/1749-7922-9-33.

29. Sarper A, Ayten A, Golbasi I, Demircan A, Isin E. Bronchogenic cyst. Tex Heart Inst J. 2003;30:105-8.

\section{Publisher's Note}

Springer Nature remains neutral with regard to jurisdictional claims in published maps and institutional affiliations.
Ready to submit your research? Choose BMC and benefit from:

- fast, convenient online submission

- thorough peer review by experienced researchers in your field

- rapid publication on acceptance

- support for research data, including large and complex data types

- gold Open Access which fosters wider collaboration and increased citations

- maximum visibility for your research: over 100M website views per year

At BMC, research is always in progress.

Learn more biomedcentral.com/submissions 